\title{
PENDEKATAN SISTEM MANAJEMEN STRATEGIS BERBASIS \\ BALANCED SCORECARD \\ (Analisa Kualitatif Kinerja PT. IMPAQ ERA BARU, Perusahaan Furnitur, Tahun 2006 Hingga 2010)
}

\author{
Oleh: \\ Denny Andriana \\ (Dosen Program Studi Akuntansi Universitas Pendidikan Indonesia)
}

\begin{abstract}
Abstrak
Era globalisasi telah mengubah pola kerja perusahaan. Jika selama ini perusahaan dengan modal besar yang dapat mengalahkan perusahaan dengan modal kecil, namun sejak arus "dunia tanpa batas" mulai muncul, perusahaan yang dapat bergerak cepat yang dapat mengambil peluang pasar yang ada dibandingkan perusahaan yang lambat dalam bertindak. PT. IMPAQ ERA BARU, perusahaan furnitur, berupaya menguasai pasar dan mengharapkan hasil optimal. Namun, tolak ukur keberhasilan suatu perusahaan tidak saja ditentukan oleh seberapa optimal mereka dapat menfaatkan seluruh sumber daya ekonomi dan faktor - faktor produksi yang ada, melainkan juga kemampuan untuk mengembangkan inovasi serta meningkatkan kreativitas perusahaan. Keadaan tersebut memperkuat kebutuhan PT. IMPAQ ERA BARU akan suatu sistem manajemen strategis dan pendekatan sistem pengukuran kinerja yang tepat agar dapat meningkatkan keunggulan kompetitif perusahaan, terutama dengan menangkap peluang pasar yang ada sekaligus mereduksi kelemahan internal perusahaan. Ancaman yang muncul dalam persaingan dapat menjadi alat peringatan bagi PT. IMPAQ ERA BARU untuk segera berbenah dan mengerahkan seluruh potensi yang ada agar dapat menjadi pemimpin dalam industri furnitur ini. Rancangan Pendekatan Sistem Pengukuran Kinerja Berbasis Balanced Scorecard yang diusulkan dalam penelitian ini dapat digunakan untuk mencapai tujuan tersebut dan memenuhi sebagian besar visi dan misi PT. IMPAQ ERA BARU untuk mencapai kinerja operasional yang efisien dan keuangan yang optimal
\end{abstract}

Kata Kunci: Sistem, Kinerja, Balanced Scorecard

\section{Latar Belakang}

Perkembangan industri furnitur di Indonesia selama ini tidak lepas dari berbagai kebijakan yang dikeluarkan pemerintah. Pemberian kemudahan dalam berinvestasi dan perolehan bahan baku mendorong industri furnitur semakin berkembang. Bahkan industri furnitur yang sempat terpuruk dimasa krisis global tahun 2008 kini sudah mulai bangkit kembali.

Banyaknya pembangunan apartemen dan kompleks perumahan di daerah daerah penyangga ibu kota ikut meningkatkan permintaan akan furnitur. Selain itu, furnitur juga dibutuhkan untuk menyediakan perlengkapan perkantoran, hotel dan bangunan komersial lainnya. Besarnya pasar furnitur menambah jumlah perusahaan yang bergerak di industri furnitur dari waktu ke waktu. Hal ini secara tidak langsung akan meningkatkan persaingan.

Para pengusaha industri furnitur berlomba untuk menguasai pasar dan mengharapkan hasil optimal. Tolak ukur keberhasilan suatu perusahaan tidak saja ditentukan oleh seberapa optimal mereka dapat menfaatkan seluruh sumber daya ekonomi 
dan faktor - faktor produksi yang ada, melainkan juga kemampuan untuk mengembangkan inovasi serta meningkatkan kreativitas perusahaan.

PT. IMPAQ ERA BARU, sebuah perusahaan furnitur, berupaya untuk secara berkelanjutan memelihara dan meningkatkan kualitas produknya dengan mengandalkan perpaduan sumber daya manusia yang memiliki keahlian tinggi dan pemanfaatan teknologi berupa mesin mutakhir agar dapat bersaing memenuhi kebutuhan pasar furnitur.

Namun hal tersebut dirasa belum cukup dijadikan sebagai satu standar kesuksesan dalam bersaing di industri furnitur. Mengukur kesuksesan merupakan salah satu faktor penting bagi perusahaan untuk terus meningkatkan kualitas diri. Selama ini, aspek keuangan merupakan aspek yang paling ditekankan dan diperhatikan perusahaan dibandingkan aspek yang lain. Pengukuran terhadap aspek ini lebih mudah dijadikan sebagai parameter pada pengukuran hasil akhir dari kegiatan atau keputusan masa lampau yang telah dijalankan perusahaan. Return on Investment (ROI) dan Earning per Share (EPS) merupakan salah satu indikator umum dari sekian banyak rasio lainnya yang digunakan untuk mengukur keberhasilan kinerja perusahaan.

Standar kinerja perusahaan sendiri hendaknya merupakan hasil yang dapat diukur dan menggambarkan kondisi empirik suatu perusahaan dalam periode tertentu dengan mengacu pada standar yang ditetapkan dari berbagai ukuran yang disepakati. Untuk mengetahui kinerja yang dicapai maka dilakukan proses penilaian kinerja. Tujuan penilaian kinerja secara umum pada dasarnya adalah sebagai alat untuk memotivasi pegawai mencapai sasaran perusahaan dan membuahkan hasil yang diinginkan oleh perusahaan. Standar perilaku dapat berupa kebijakan manajemen atau rencana formal yang dituangkan dalam rencana stratejik, program dan anggaran perusahaan. Penilaian kinerja juga digunakan untuk menekan perilaku yang tidak semestinya dan untuk merangsang dan menegakan perilaku yang semestinya diinginkan, melalui umpan balik hasil kinerja pada waktunya serta penghargaan, baik yang bersifat intrinsik maupun ekstrinsik.

Beberapa metode penilaian kinerja yang digunakan selama ini pada umumnya menggunakan parameter dan standar ukuran keuangan, sesuai dengan tujuan perusahaan yaitu memuaskan para pemengang saham (shareholders), namun kurang memperhatikan ukuran kinerja yang lebih luas yaitu memuaskan para pemangku kepentingan (stakeholders). Atkinson, et. Al. (1995) menyatakan pengukuran kinerja sebagai berikut:

"Performance measurement is perhaps the most important, most misunderstood, and most difficult task in management accounting. An effective system of performance measurement containts critical performance indicator (performance measures) that (1) consider each activity and the organization it self from the customer's perspective, (2) evaluate each activity using customer-validated measure of performance, (3) consider all facets of activity performance that affect customers and, therefore, are comprehensive, and (4) provide feed-back to help organization members identity problems and opportunities for improvement".

Pernyataan di atas dapat diartikan bahwa penilaian kinerja merupakan hal yang sangat penting walaupun memiliki kemungkinan untuk disalah-artikan, dan merupakan tugas yang paling sulit dalam akuntansi manajemen. Sistem penilaian kinerja yang efektif sebaiknya mengandung indikator kinerja, yaitu: (1) memperhatikan setiap aktivitas organisasi dan menekankan pada perspektif pelanggan, (2) menilai setiap aktivitas dengan menggunakan alat ukur kinerja yang mengesahkan pelanggan, (3) memperhatikan semua aspek aktivitas kinerja secara komprehensif yang mempengaruhi pelanggan, dan (4) menyediakan informasi berupa umpan balik untuk membantu anggota organisasi mengenali permasalahan dan peluang untuk melakukan perbaikan. 
Melihat permasalahan di atas, sistem Balanced Scorecard dikembangkan sebagai reaksi atas ketidakmampuan penilaian kinerja tradisional. Sistem Balanced Scorecard berguna untuk mengidentifikasi kebutuhan yang harus dikembangkan perusahaan untuk bersaing dalam jangka panjang.

Sistem ini pertama kali diperkenalkan pada tahun 1992 oleh Robert S. Kaplan, seorang Professor yang mengajar pada Harvard Business School, dan David P. Norton, Presiden dari Renaissance Solution, Inc., sebuah perusahaan konsultan internasional yang berspesialisasi pada pengukuran kinerja dan pembenahan organisasi.

Kaplan dan Norton mencoba melakukan pendekatan yang mengukur kinerja perusahaan dengan mempertimbangkan empat (4) aspek atau perspektif, yakni perspektif keuangan, pelanggan, proses bisnis internal, serta proses belajar dan berkembang. Keempat perspektif tersebut merupakan penjabaran dan upaya penerjemahan visi dan strategi perusahaan ke dalam terminologi operasional.

Menurut Kaplan dan Norton (1996), Balanced Scorecard merupakan:

"... a set of measures that gives to managers a fast but comprehensive view of the business...includes financial measures that tell the results of actions already taken... complements the financial measures with operational measures on customer satisfaction, internal processes, and the organization's innovation and improvement activitiesoperational measures that are the drivers of future financial performance."

Balanced Scorecard lebih dari sekedar sistem pengukuran taktis atau operasional. Perusahaan menggunakan scorecard sebagai sebuah sistem manajemen strategis untuk mengelola strategi jangka panjang. Perusahaan juga menggunakan fokus pengukuran scorecard untuk menghasilkan berbagai proses manajemen penting: (1) Memperjelas dan menerjemahkan visi dan strategi; (2) Mengkomunikasikan dan mengaitkan berbagai tujuan dan ukuran strategis; (3) Merencanakan, menetapkan sasaran, dan menyelaraskan berbagai inisiatif strategis; (4) Meningkatkan umpan balik dan pembelajaran strategis.

\section{Rumusan Masalah}

PT. IMPAQ ERA BARU, perusahaan yang bergerak di bidang furnitur, merupakan objek penelitian rancangan implementasi Balanced Scorecard dalam upayanya untuk meningkatkan kinerja. Ada 2 permasalahan pokok yang menjadi objek penelitian:

1. Mengidentifikasi kinerja manajemen dan perencanaan strategis PT. IMPAQ ERA BARU dalam kurun waktu tahun 2006 hingga tahun 2010.

2. Mengidentifikasi peluang rancangan konsep Balanced Scorecard untuk dijadikan alternatif pendekatan strategis dalam memecahkan masalah yang dihadapi.

\section{Kerangka Pemikiran}

Balanced scorecard adalah fenomena baru dalam perkembangan dunia usaha. Namun, tidak sedikit perusahaan yang meragukan akan penggunaan sistem ini untuk memperbaiki kinerja internal perusahaan. Hal ini sangat wajar mengingat Balanced Scorecard semula dikembangkan dengan tujuan sebagai sistem pengukuran kinerja. Pengembangan ini diawali oleh penelitian studi kasus atas berbagai perusahaan mengenai kinerja pada organisasi di masa depan yang disponsori oleh Nolan Norton Institute, suatu lembaga riset dari KPMG.

Hasil dari studi yang mengambil tema "Pengukuran Kinerja dalam Organisasi Masa Depan" kemudian diterbitkan dalam sebuah artikel berjudul "Balanced ScorecardMeasures that Driver Performance" dalam Harvard Business Review (Januari-Pebruari 1992). Kesimpulan yang dapat diperoleh dari hasil studi tersebut adalah bahwa ternyata 
untuk mengukur kinerja eksekutif di masa depan, diperlukan ukuran komprehensif yang mencakup empat perspektif; keuangan, pelanggan, proses bisnis internal, dan pembelajaran dan pertumbuhan.

Balanced Scorecard menerjemahkan misi dan strategi ke dalam berbagai tujuan dan ukuran, yang tersusun ke dalam empat perspektif: keuangan, pelanggan, proses bisnis internal, serta pembelajaran dan pertumbuhan. Pemberian istilah balanced scorecard menurut Kaplan adalah untuk mencerminkan keseimbangan antara sasaran jangka pendek dan jangka panjang antara ukuran keuangan dan non-keuangan, antara indikator lagging dan leading, antara perspektif kinerja internal dan eksternal.

Pengukuran kinerja keuangan akan menunjukkan apakah perencanaan dan pelaksanaan strategi memberikan perbaikan yang mendasar bagi keuntungan perusahaan. Perbaikan - perbaikan ini tercermin dalam sasaran - sasaran yang secara khusus berhubungan dengan keuntungan yang terukur, pertumbuhan usaha dan nilai pemegang saham.

Pembentukan sebuah Balanced Scorecard dalam perspektif keuangan dapat mendorong unit bisnis untuk mengaitkan tujuan dari aspek keuangan dengan strategi perusahaan. Perspektif keuangan menjadi fokus utama dari tujuan dan ukuran dibandingkan semua perspektif scorecard lainnya. Ini disebabkan karena pada akhirnya tujuan akhir dari pembentukan scorecard diharapkan mampu untuk melipatgandakan kekayaan perusahaan. Setiap ukuran yang digunakan harus merupakan bagian dari hubungan sebab akibat yang pada akhirnya akan meningkatkan kinerja keuangan.

Scorecard harus menjelaskan strategi perusahaan, dimulai dengan tujuan keuangan jangka panjang dan kemudian mengaitkannya dengan berbagai urutan tindakan yang harus diambil berkenaan dengan proses keuangan, pelanggan, proses internal, dan para pekerja serta sistem untuk menghasilkan kinerja ekonomis jangka panjang yang diinginkan oleh perusahaan.

Dalam perspektif keuangan, scorecard memberikan kesempatan top level management dari setiap unit bisnis untuk menetapkan ukuran berbagai variabel yang dianggap paling penting untuk menciptakan dan mendorong tercapainya tujuan jangka panjang. Faktor pendorong untuk mencapai tujuan jangka panjang dalam perspektif keuangan harus disesuaikan menurut jenis industri, lingkungan persaingan dan strategi setiap unit bisnis.

Perspektif pelanggan memfokuskan diri untuk memenuhi kebutuhan pelanggan pada tingkat kepuasan maksimum. Jika produk yang ditawarkan mendapat tanggapan positif dari pelanggan, maka akan berpengaruh positif terhadap kinerja keuangan perusahaan.

Berbagai proses internal dan upaya pengembangan perusahaan harus diarahkan berdasarkan perspektif pelanggan. Kebanyakan upaya tersebut diarahkan untuk menentukan cara meningkatkan dan meyakinkan loyalitas pelanggan. Langkah yang dapat dilakukan untuk menopang upaya tersebut adalah dengan memahami dan memenuhi kebutuhan pelanggan yang bervariasi. Perusahaan harus memperoleh gambaran secara pasti tentang arti produk atau jasa bagi para pelanggannya. Jika pelanggannya merupakan pelanggan industri yang mengelola jasa, maka perusahaan perlu bertanya apakah ada dari produknya yang dapat memberikan nilai tambah bagi pelanggannya. Seberapa besarkah manfaat yang daapt dirasakan pelanggannya dalam penentuan harga bila dibandingkan dengan nilai - nilai lainnya, seperti pelayanan, kualitas produk atau jasa, fungsinya baik untuk jangka pendek ataupun jangka panjang, dan sebagainya. Setelah perusahaan memperoleh feedback atau masukan dari pelanggan, perusahaan dapat merumuskan rangkaian strategi yang dapat digunakan sebagai dasar untuk menentukan kebijakan makro perusahaan. 
Pengukuran kinerja pada perspektif pelanggan, menurut Sony Yuwono (2002) yang dikutip dari buku Robert S. Kaplan dan David P. Norton, The Balanced Scorecard: Translating Strategy into Action (1996, hal. 71), memiliki dua kelompok pengukuran, yaitu: (1) Customer Core Measurement; (2) Customer Value Preposition.

Customer core measurement memiliki beberapa komponen pengukuran, yaitu: (1) Market Share: Pengukuran dengan menggunakan market share menunjukkan bagian yang dikuasai perusahaan atas keseluruhan pasar yang ada, yang meliputi antara lain: jumlah pelanggan, jumlah penjualan, dan volume unit penjualan; (2) Customer Retention: Pengukuran dengan menggunakan customer retention menunjukkan sejauh mana perusahaan dapat mempertahankan hubungan dengan konsumen; (3) Customer Acquisition: Pengukuran dengan menggunakan customer acquisition menunjukkan tingkat di mana suatu unit bisnis mampu menarik pelanggan baru atau memenangkan bisnis baru; (4) Customer Satisfaction: Pengukuran dengan menggunakan customer satisfaction menunjukkan sejauh mana pelanggan dapat terpuaskan kebutuhannya; (5) Customer Profitability: Mengukur laba bersih dari seorang pelanggan atau segmen setelah dikurangi biaya yang khusus diperlukan untuk mendukung pelanggan tersebut.

Customer Value Proposition merupakan pemicu kinerja yang terdapat pada core value proposition yang didasarkan pada product/service attributes, customer relationship, dan image and relationship.

Product/service attributes meliputi fungsi produk atau jasa, harga, dan kualitas. Pelanggan memiliki kecenderungan yang berbeda - beda atas produk yang ditawarkan. Pelanggan ada yang lebih mengutamakan fungsi dari produk atau jasa. Ada juga beberapa pelanggan yang lebih tertarik pada kualitas produk atau jasa dan sebagian lain menaruh perhatian besar pada harga yang murah. Sementara di sisi lain, perusahaan harus mengidentifikasi apa yang diinginkan pelanggan atas produk yang ditawarkan. Sehingga pengukuran kinerja harus ditetapkan berdasarkan hal tersebut.

Gambar 1. Perspektif Pelanggan: Tolak Ukur Utama

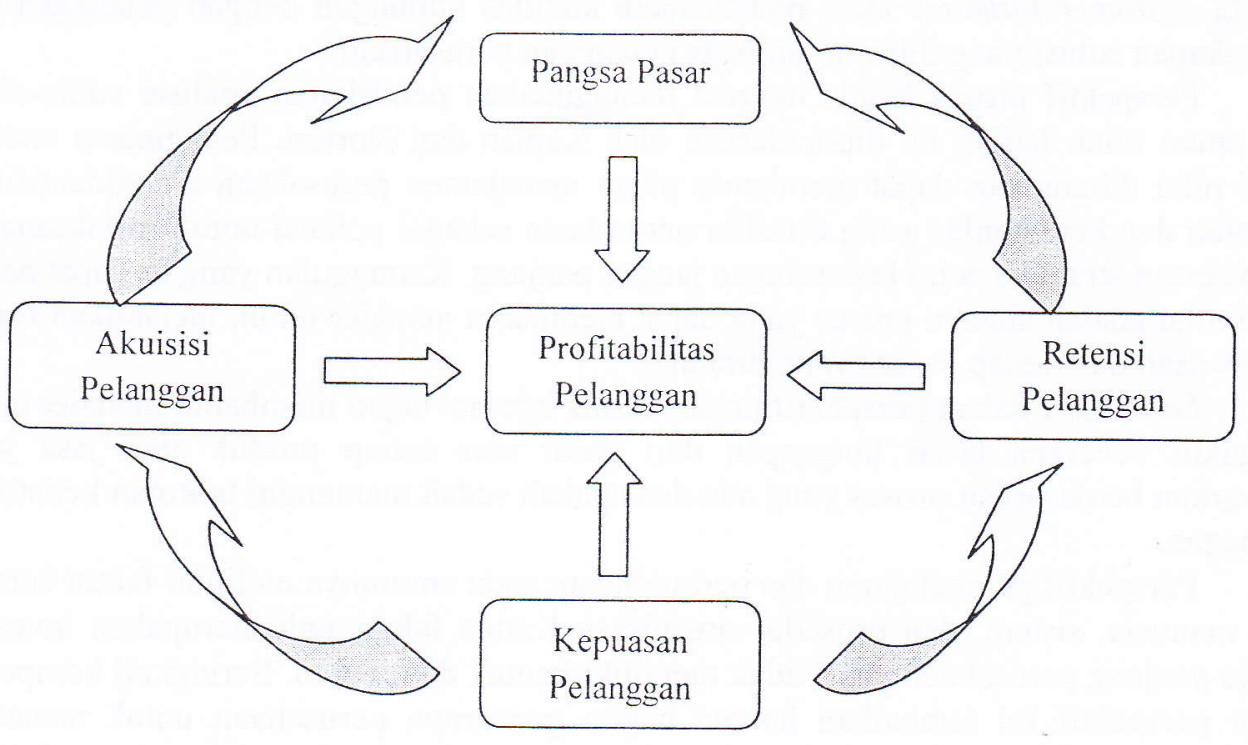

Sumber: Robert S. Kaplan dan David P. Norton, Balanced Scorecard: Menerapkan Strategi Menjadi Aksi, Terj. Peter R. Yosi Pasla, Jakarta, Erlangga, 2000, hal. 60 
Customer relationship adalah bagaimana perusahaan mampu memelihara hubungan yang baik dengan pelanggannya. Menjaga hubungan baik juga termasuk di dalamnya adalah menyangkut perasaan pelanggan terhadap pembelian produk yang ditawarkan perusahaan. Perasaan konsumen sangat dipengaruhi oleh responsivitas dan komitmen perusahaan terhadap pelanggan berkaitan dengan masalah waktu penyampaian. Waktu merupakan komponen yang penting dalam persaingan perusahaan. Konsumen pada umumnya menganggap penyelesaian pesanan yang cepat dan tepat waktu sebagai faktor yang penting bagi kepuasaan mereka.

Image and reputation dapat dilakukan melalui mekanisme pemasaran yang tepat dan menjaga kualitas seperti yang dijanjikan. Image dan reputasi merupakan aset perusahaan yang tidak berwujud namun berkaitan langsung dengan representasi perusahaan di mata pelanggan.

Sebuah organisasi akan melakukan tiga pilihan strategi dalam rangka melakukan differensiasi di pasar seperti di bawah ini: (1) Product Leadership. Perusahaan yang menekankan pada strategi ini mendorong produknya untuk mencoba sesuatu yang belum diketahui, belum dicoba atau yang sangat diinginkan; (2) Customer Intimacy. Perusahaan ysang melakukan strategi ini membangun ikatan dengan pelanggannya dan produk serta jasa yang dibutuhkan; (3) Operational Excellence. Perusahaan dengan strategi ini memberikan kombinasi antara kualitas, harga, dan kemudian membeli yang tidak dimiliki oleh perusahaan lain.

Secara umum perusahaan akan menekankan pada salah satu strategi yang ada dan mempertahankan pada dua strategi lainnya. Strategi yang berbeda ini akan memberikan penekanan tertentu pada proporsi nilai yang berbeda pula.

Perusahaan yang menekankan pada strategi operational excellence perlu meningkatkan ukuran ataupun standard yang digunakan, seperti harga yang kompetitif, customer perceived quality, dan lead time serta on-time delivery untuk pembelian. Perusahaan yang menggunakan strategi product leadership akan menekankan pada functionality, features, dan kinerja produk atau jasa. Sedangkan perusahaan dengan strategi customer intimacy akan menekankan kualitas hubungan dengan pelanggan dan kelengkapan solusi yang ditawarkan pada pelanggan perusahaan.

Perspektif proses bisnis internal menggunakan pendekatan analisis value-chain atau rantai nilai. Istilah ini dipopulerkan oleh Kaplan dan Norton. Penggunaan analisis rantai nilai diharapkan dapat membantu pihak manajemen perusahaan mengidentifikasi kekuatan dan keunggulan yang dimiliki perusahaan sebagai potensi untuk melaksanakan perencanaan strategis demi kepentingan jangka panjang. Keunggulan yang terdapat dalam rantai nilai adalah adanya proses yang dapat membantu manajer untuk melakukan fungsi pengawasan dari setiap proses yang dilalui.

Scorecard dalam perspektif proses bisnis internal dapat membantu manajer untuk mengukur seberapa besar tanggapan dari pasar atas setiap produk atau jasa yang ditawarkan berdasarkan proses yang ada dan apakah sudah memenuhi tuntutan kebutuhan pelanggan.

Perspektif pembelajaran dan pertumbuhan pada umumnya meliputi faktor sumber daya manusia, sistem, dan prosedur organisasi. Ketiga faktor tadi merupakan investasi jangka panjang perusahaan yang tidak memiliki bentuk dan wujud. Seringkali komponẹn dalam perspektif ini terabaikan karena begitu gencarnya perusahaan untuk mencapai ketiga perspektif lainnya. Contoh yang paling sering diungkapkan dalam perspektif ini adalah pelatihan pegawai dan pembentukan budaya perusahaan.

Hasil dari pengukuran ketiga perspektif sebelumnya pada umumnya akan menunjukkan kesenjangan yang besar antara kemampuan orang, sistem, dan prosedur yang ada saat ini dengan yang dibutuhkan untuk mencapai kinerja yang diinginkan. 
Alasan tersebut memaksa perusahaan melakukan investasi di ketiga faktor tersebut untuk mendorong perusahaan menjadi organisasi pembelajar (learning organization).

Dalam perspektif pembelajaran dan pertumbuhan, perusahaan melihat tolak ukur: (1) Employee Capabilities; (2) Information System Capabilities, dan (3)Motivation, Empowermentm and Allignment.

Salah satu tantangan besar bagi perusahaan adalah mengelola sumber daya manusianya. Upaya secara berkelanjutan untuk mengelola kualitas sumber daya manusianya tidak terlepas dari tiga pengukuran umum yang sering digunakan oleh perusahaan. Tiga pengukuran tersebut adalah: (1) Kepuasan pekerja: Tujuan kepuasan pekerja menyatakan bahwa moral pekerja dan kepuasan kerja secara keseluruhan saat ini dipandang sangat penting oleh sebagian besar perusahaan; (2) Retensi Pekerja: Tujuan retensi pekerja adalah untuk mempertahankan selama mungkin para pekerja yang diminati perusahaan; (3) Mengukur produktivitas pekerja: Tujuannya adalah membandingkan keluaran yang dihasilkan oleh para pekerja tersebut dengan jumlah pekerja yang dikerahkan untuk menghasilkan keluaran tersebut.

Kebutuhan arus informasi yang dapat diandalkan memerlukan beberapa perangkat penunjang. Informasi yang tepat waktu dan akurat dapat dipenuhi dengan memanfaatkan teknologi yang mampu membuat sistem arus informasi menjadi lebih efisien dan efektif. Para pegawai di dalam perusahaan, baik level manajemen maupun level staf, diharapkan mampu menggunakan teknologi dalam mengirimkan maupun menerima informasi yang ada. Hal ini untuk menunjang proses pengambilan keputusan yang terkadang memerlukan waktu yang cepat tanpa menghilangkan keakuratan data maupun informasi yang digunakan.

Perspektif pembelajaran dan pertumbuhan penting untuk menjamin adanya proses yang berkesinambungan terhadap upaya pemberian motivasi dan inisiatif yang sebesar - besarnya bagi pegawai. Meskipun pegawai yang terampil dilengkapi dengan akses informasi yang luas, tidak menjamin dapat memberikan kontribusi bagi keberhasilan perusahaan jika mereka tidak termotivasi bertindak untuk kepentingan terbaik perusahaan, atau jika mereka tidak diberikan kebebasan membuat keputusan dan mengambil tindakan.

Upaya untuk menjamin proses pembelajaran dan pertumbuhan bagi para pegawainya dapat dilakukan dengan cara memberikan delegasi wewenang yang memadai dalam mengambil keputusan. Proses pendelegasian wewenang harus disertai dengan tambahan tanggung jawab yang diiringi dengan upaya penyesuaian yang terus menerus sejalan dengan tujuan organisasi.

\section{Metode Penelitian}

Metode yang digunakan dalam penelitian ini terbagi atas dua (2) bagian utama:

1. Metode Penelitian Kepustakaan (Library Research Method)

Metode ini lebih mengedepankan penelitian literatur bahan - bahan pustaka sebagai dasar untuk mendapatkan landasan teoritis yang memadai serta informasi yang terkait dengan penelitian ini. Teori sistem Balanced Scorecard dan ke-empat perspektifnya akan menjadi dasar dalam menganalisa permasalahan yang ada di PT. IMPAQ ERA BARU.

2. Metode Penelitian Lapangan (Field Research Method)

Metode ini dilakukan dengan cara melakukan penelitian secara langsung ke PT. IMPAQ ERA BARU yang bersangkutan untuk memperoleh data - data primer yang diperlukan dalam penelitian ini. Adapun pelaksanaan dari metode ini akan dilakukan dengan cara: (1) Data Collecting (Mengumpulkan data/keterangan yang dibutuhkan) yang diperoleh dari pihak internal PT. IMPAQ ERA BARU yang 
bersangkutan sesuai dengan kebutuhan penelitian guna memperoleh data - data primer; (2) Interview (Wawancara) dengan pihak - pihak yang terkait yang mengetahui secara lengkap masalah yang akan dibahas.

\section{Hasil Penelitian dan Pembahasan}

\section{Analisa lingkungan industri PT. IMPAQ ERA BARU}

PT. IMPAQ ERA BARU merupakan bagian dari sebuah lingkungan industri, khususnya industri furnitur. Artinya, setiap kebijakan yang dikeluarkan, strategi yang dirumuskan, dan keputusan yang dihasilkan, harus mengikuti perubahan yang terjadi dalam industri tempat beroperasinya perusahaan. Bebrapa perubahan yang dimaksud tersebut mungkin dapat dipengaruhi oleh perusahaan tetapi ada perubahan yang sulit untuk dikendalikan. Porter (1980) menyatakan bahwa terdapat lima kekuatan yang mempengaruhi industri, yaitu: ancaman perusahaan baru yang memasuki industri, kekuatan pemasok, kekuatan pembeli, dampak produk substitusi, dan persaingan dalam industri.

Banyaknya pemain baru dalam industri furnitur dapat memberikan ancaman bagi PT. IMPAQ ERA BARU. Namun begitu, ancaman yang mungkin timbul dari masuknya perusahaan baru ke dalam industri furnitur untuk bersaing merebut pasar, dapat diminimalisasi dengan cara membangun hambatan bagi perusahaan baru tersebut. Hambatan yang dapat dilakukan antara lain dengan cara mempertahankan pelanggan yang ada dengan memberikan pelayanan ekstra pasca transaksi, mengurangi biaya - biaya yang tidak memberikan nilai tambah bagi aktivitas produksi dan operasional perusahaan, diferensiasi produk, dan sebagainya.

Kekuatan pemasok atau suppliers dapat dipengaruhi oleh beberapa faktor. Faktor tersebut diantaranya adalah volume penjualan relatif dibandingkan dengan daya beli konsumen. Maksudnya adalah ketika barang yang dimiliki oleh pemasok sangat dibutuhkan oleh PT. IMPAQ ERA BARU, maka posisi tawar pemasok untuk menentukan harga jual menjadi sangat dominan. Selama PT. IMPAQ ERA BARU belum menemukan substitusi atas bahan baku yang diperoleh dari pemasok yang sama, maka posisi tawar PT. IMPAQ ERA BARU menjadi sangat lemah karena memiliki ketergantungan yang tinggi kepada pemasoknya.

Kekuatan pembeli tidak terlalu berbeda dengan kekuatan pemasok. Kebutuhan pembeli yang beragam berpengaruh terhadap tingkat konsumsi atas furnitur hasil produksi PT. IMPAQ ERA BARU. Keberagaman tersebut membuat pembeli memiliki daya tawar yang kuat terhadap produk - produk karya PT. IMPAQ ERA BARU. Oleh karena itu, kekuatan pemasok dan pembeli secara langsung sangat berpengaruh terhadap kegiatan operasional perusahaan. Hal yang menjadi kendala umum adalah apakah internal perusahaan mampu menjaga kedua kekuatan tersebut dan mempertahankan hubungan kemitraan yang sudah terjalin dengan baik.

Produk substitusi di lain pihak dapat mengurangi potensi pendapatan PT. IMPAQ ERA BARU. Ketika pilihan produk banyak tersedia di pasar dengan harga yang kompetitif, konsumen dapat memilih produk yang sama seperti yang ditawarkan PT. IMPAQ ERA BARU namun dengan harga yang relatif lebih rendah. Hal ini menjadi tantangan bagi manajemen PT. IMPAQ ERA BARU agar mampu memproduksi barang berkualitas namun di saat bersamaan mampu menekan biaya produksi pada titik terendah. 


\section{Gambar 2. Kekuatan - Kekuatan dalam Analisis Industri}

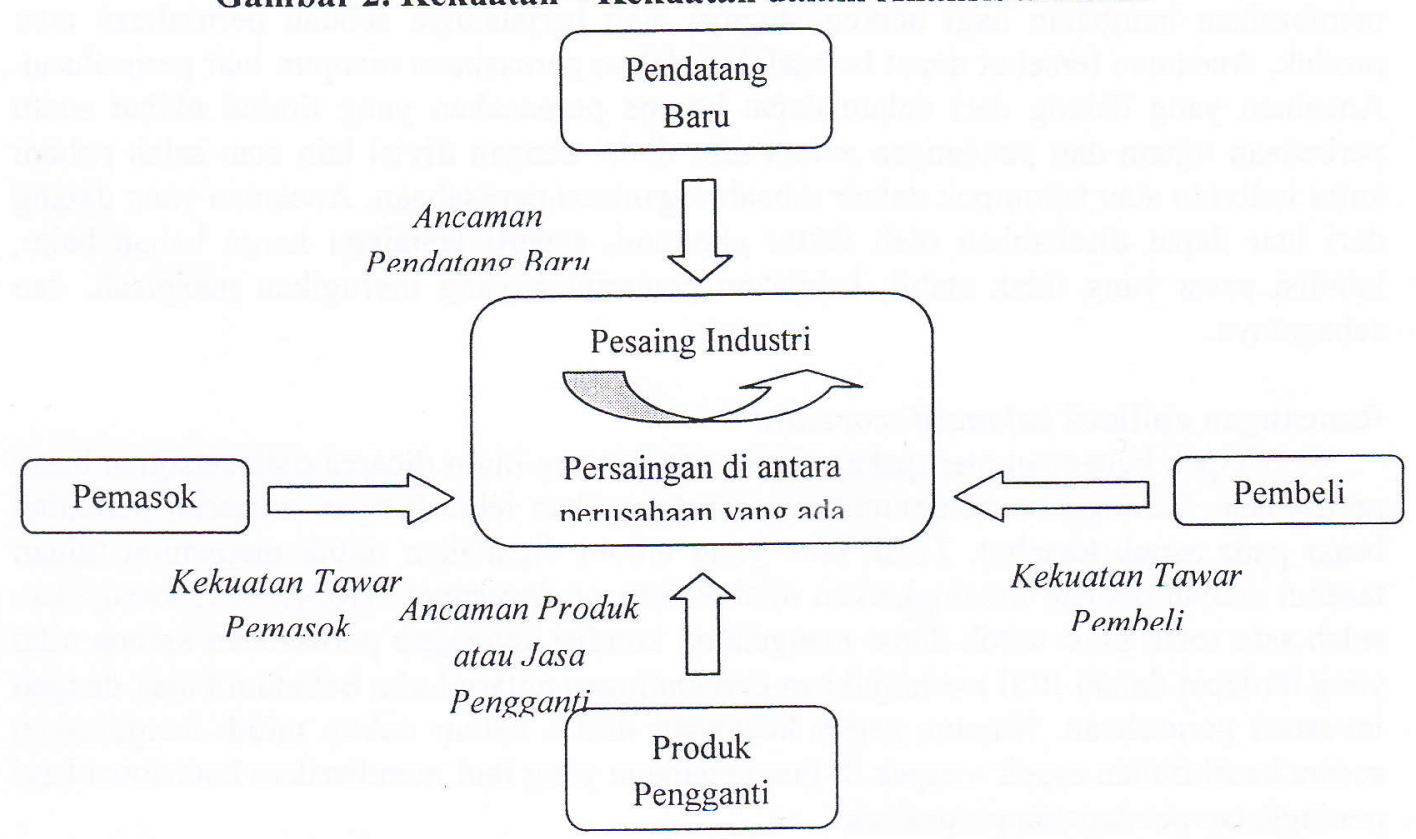

Sumber: Porter, Competitive Strategy: Techniques for Analyzing Industries and Competitors: New York, The Free Press, 1980, hal. 6

\section{Analisa internal PT. IMPAQ ERA BARU}

Analisa internal terhadap kondisi PT. IMPAQ ERA BARU dapat meliputi analisa terhadap kekuatan (strength), kelemahan (weakness), peluang (opportunities), dan ancaman (threat) atau dikenal dengan istilah analisa SWOT. Teknik analisa SWOT dianggap sebagai teknik paling dasar yang berguna untuk melihat suatu topik atau pembahasan dari 4 (empat) sisi yang berbeda.

Kualitas produk dengan desain melebihi ekspektasi pelanggan merupakan kekuatan utama yang dimiliki oleh PT. IMPAQ ERA BARU. Dengan pengalaman lebih dari 10 tahun berkecimpung dalam aktivitas produksi furnitur, manajemen PT. IMPAQ ERA BARU memperoleh banyak pelajaran dan pengalaman. Perpaduan yang harmonis antara sumber daya manusia yang mumpuni dalam menciptakan inovasi produk dengan mesin produksi mutakhir membuat kualitas furnitur yang dihasilkan tetap terjaga.

Kemacetan modal kerja merupakan salah satu kendala yang selama ini dialami oleh PT. IMPAQ ERA BARU. Tersendatnya pengembalian piutang dari pelanggan sangat berpengaruh terhadap kelancaran proses produksi, karena modal kerja yang dibutuhkan untuk pembelian bahan baku menjadi terhambat. Dampak negatif akibat hal tersebut adalah perputaran arus kas di dalam perusahaan menjadi tidak baik dan cenderung negatif.

Peluang merupakan faktor positif yang berasal dari lingkungan yang memberikan kesempatan bagi perusahaan untuk memanfaatkannya. Peluang tidak hanya berupa kesempatan dalam hal mendapatkan modal, tetapi dapat juga berupa respon masyarakat atau isu yang sedang diangkat.

Perkembangan bisnis properti merupakan peluang bisnis yang sangat besar bagi PT. IMPAQ ERA BARU untuk mengembangkan jaringan pemasaran produk mereka. Pulihnya pasar global dari krisis tahun 2008 dan membaiknya nilai tukar rupiah juga merupakan peluang besar untuk pengembangan bisnis PT. IMPAQ ERA BARU, terutama untuk memenuhi kebutuhan pasar ekspor. 
Ancaman merupakan faktor negatif yang berasal dari lingkungan dan dapat memberikan hambatan bagi berkembangnya atau berjalannya sebuah perusahaan atau produk. Ancaman tersebut dapat berasal dari dalam perusahaan maupun luar perusahaan. Ancaman yang datang dari dalam dapat berupa perpecahan yang timbul akibat suatu perbedaan tujuan dan pandangan antara satu divisi dengan divisi lain atau salah paham antar individu atau kelompok dalam sebuah organisasi perusahaan. Ancaman yang datang dari luar dapat disebabkan oleh faktor ekonomi, seperti kenaikan harga bahan baku, kondisi pasar yang tidak stabil, kebijakan pemerintah yang merugikan pengusah, dan sebagainya.

\section{Rancangan aplikasi balanced scorecard}

Aspek keuangan merupakan tujuan utama yang ingin dicapai oleh sebagian besar perusahaan. Sehingga pada umumnya perusahaan akan lebih banyak menaruh perhatian besar pada aspek tersebut. Tolak ukur yang umum digunakan untuk memenuhi tujuan tesebut adalah dengan meningkatkan nilai Return on Investment (ROI). ROI merupakan salah satu tolak ukur untuk dapat mengetahui kondisi keuangan perusahaan karena nilai yang terdapat dalam ROI menunjukkan perbandingan antara Laba Sebelum Pajak dengan investasi perusahaan. Namun, aspek keuangan dirasa belum cukup untuk menjelaskan secara keseluruhan aspek - aspek di luar keuangan yang ikut memberikan kontribusi bagi peningkatan pendapatan perusahaan.

Balanced Scorecard merupakan metode pengukuran kinerja yang diperkenalkan oleh Kaplan dan Norton yang bertujuan untuk dapat menjawab permasalahan yang sering kali muncul di dalam perusahaan. Balanced scorecard tersebut dapat menerjemahkan misi dan strategi perusahaan ke dalam berbagai tujuan dan ukuran, yang tersusun ke dalam empat perspektif, yaitu: Perspektif Keuangan, Perspektif Konsumen, Perspektif Proses Bisnis Internal, dan Perspektif Pembelajaran dan Pertumbuhan.

PT. IMPAQ ERA BARU merupakan perusahaan furnitur yang memiliki potensi sangat besar untuk menjadi perusahaan furnitur terdepan dalam menerapkan metode Balanced Scorecard guna meningkatkan kinerja perusahaannya.

Menurut Kaplan, dalam pengukuran kinerja keuangan, ada tiga hal utama yang dijadikan sebagai bahan pertimbangan berkaitan dengan adanya tahapan dari siklus bisnis, yaitu: Growth (Pertumbuhan), Sustain (Bertahan), dan Harvest (Menuai). Tahapan - tahapan tersebut menunjukkan kondisi umum suatu perusahaan yang secara khusus berkaitan dengan kondisi keuangan perusahaan.

Berikut di bawah ini adalah kondisi keuangan PT. IMPAQ ERA BARU dari sisi penjualan bersih untuk periode $2006-2010$.

Tabel 1. Laporan Penjualan Bersih 2006 - 2010 (dalam Jutaan Rupiah)

\begin{tabular}{|c|c|}
\hline TAHUN & $\begin{array}{c}\text { PENJUALAN } \\
\text { BERSIH }\end{array}$ \\
\hline 2006 & Rp. 13.095 \\
\hline 2007 & Rp. 6.420 \\
\hline 2008 & Rp. 10.139 \\
\hline 2009 & Rp. 19.546 \\
\hline 2010 & Rp. 21.749 \\
\hline
\end{tabular}

Sumber: PT. IMPAQ ERA BARU

Bila kita melihat kondisi umum kinerja keuangan PT. IMPAQ ERA BARU, saat ini perusahaan tersebut berada dalam tahapan Sustain (bertahan). PT. IMPAQ ERA BARU mencoba mempertahankan pangsa pasar yang ada dan bila memungkinkan akan terus mencoba untuk memperluas pasar dan mengembangkannya. 
Sasaran strategis yang dapat dilakukan dalam tahapan bertahan bagi PT. IMPAQ ERA BARU adalah: (1) Meningkatkan Pendapatan Perusahaan; (2) Mengelola Pendapatan Piutang

Peningkatan pendapatan dapat dilakukan dengan mempertahankan pelanggan lama sekaligus menambah kuantitas pelanggan baru dengan meluaskan pasar ekspor ke wilayah Eropa yang selama ini jarang sekali digarap. Trend positif penjualan bersih harus terus ditingkatkan agar PT. IMPAQ ERA BARU dapat bertahan dan unggul dalam persaingan.

Terdapat hubungan linear antara penjualan kredit dengan tingkat perputaran piutang. Semakin tinggi penjualan kredit maka semakin tinggi tingkat perputaran piutang yang dihasilkan, sebaliknya semakin rendah penjualan kredit maka tingkat perputaran piutang yang dihasilkan juga semakin rendah.

Tabel 2. Perputaran Piutang 2006 - 2010 (dalam jutaan Rupiah)

\begin{tabular}{|l|r|r|r|r|r|}
\hline TAHUN & $\begin{array}{c}\text { PENJUALAN } \\
\text { KREDIT } \\
\text { (A) }\end{array}$ & $\begin{array}{c}\text { PIUTANG } \\
\text { AWAL } \\
\text { (B) }\end{array}$ & $\begin{array}{c}\text { PIUTANG } \\
\text { AKHIR } \\
\text { (C) }\end{array}$ & $\begin{array}{c}\text { RATA- } \\
\text { RATA } \\
\text { D=(B+C)/2 }\end{array}$ & $\begin{array}{c}\text { TINGKAT } \\
\text { PERPUTARAN } \\
\text { PIUTANG } \\
\text { E=A:Dx1 }\end{array}$ \\
\hline 2006 & 13,066 & 1,204 & 1,563 & 1,384 & 9 \\
\hline 2007 & 6,419 & 1,563 & 1,260 & 1,412 & 5 \\
\hline 2008 & 10,139 & 1,260 & 1,809 & 1,535 & 7 \\
\hline 2009 & 19,545 & 1,809 & 2,210 & 2,009 & 10 \\
\hline 2010 & 21,748 & 2,210 & 6,274 & 4,242 & 5 \\
\hline
\end{tabular}

Sumber: PT. IMPAQ ERA BARU (diolah)

Pada tahun 2010, besarnya tingkat penjualan kredit berbanding terbalik dengan tingkat perputaran piutang. Hal ini disebabkan salah satu pelanggan PT. IMPAQ ERA BARU melakukan pembayaran piutang dengan komposisi $30 \%$ dalam bentuk mata uang Rupiah sedangkan sisanya sebesar $70 \%$ dibayar dalam bentuk aktiva tetap. Hal ini berpengaruh pada tingkat perputaran piutang pada periode atau tahun tersebut. Sementara selama tahun 2010 penerimaan pengembalian piutang yang diterima dalam bentuk mata uang rupiah hanya sebesar Rp.1.262.098.735 beserta aktiva tetap dalam bentuk 1 unit apartemen senilai 1.300 .000 .000 . Hal ini tentu saja menyebabkan terjadinya kekurangan modal kerja dan menjadi pemicu utama terjadinya kenaikan pinjaman kepada pihak ketiga untuk menutupi kekurangan modal kerja itu sendiri. Melihat permasalahan di atas, maka strategi pengelolaan piutang yang tepat harus dapat dilakukan agar arus kas perusahaan dapat kembali lancar sehingga modal kerja utama untuk membiayai aktivitas perusahaan dapat terpenuhi.

Dua sasaran strategis yang dapat dilakukan dalam tahapan bertahan tidak terlepas dari penggunaan tolak ukur keuangan sebagai dasar penilaian kinerja. Tolak ukur keuangan yang dapat dijadikan untuk menilai keberhasilan pencapaian strategis PT. IMPAQ ERA BARU dalam hal pendapatannya adalah sebagai berikut: (1) Return on Assets (ROA), yaitu persentase laba kotor yang dapat dicapai perusahaan dibandingkan dengan total aktiva perusahaan. Kenaikan atau penurunan ROA dari satu periode akuntansi ke periode akuntansi berikutnya dapat dijadikan ukuran pertumbuhan pendapatan perusahaan. Jika tolak ukur ini di rata - ratakan untuk beberapa periode, akan dihasilkan tingkat pertumbuhan pendapatan rata - rata; (2) Profit Margin on Sales, kenaikan atau penurunan laba sebagai akibat dari kenaikan atau penurunan penjualan dari satu periode ke periode berikutnya dapat digunakan untuk mengukur pendapatan perusahaan. Jika tolak ukur ini di rata - ratakan untuk beberapa periode, akan menghasilkan tingkat pertumbuhan rata - rata (average growth rate); (3) Receivable 
Turnover, tingkat perputaran piutang (receivable turnover) dimaksudkan untuk mengukur likuiditas atau aktivitas dari piutang perusahaan. Semakin tinggi tingkat perputaran piutang suatu perusahaan maka semakin baik pengelolaan piutangnya.

Berbagai proses internal dan upaya pengembangan perusahaan dapat diarahkan menggunakan dasar perspektif pelanggan. Hal tersebut dapat dilakukan dengan cara meningkatkan dan meyakinkan loyalitas pelanggan. Langkah - langkah yang dapat dilakukan untuk menopang upaya tersebut adalah dengan cara memahami apa yang harus dilakukan dalam menghadapi kebutuhan pelanggan yang bervariasi.

Sasaran strategis PT. IMPAQ ERA BARU yang dapat diterapkan dalam perspektif pelanggan adalah: (1) Meningkatkan Loyalitas Pelanggan Melalui Pelayanan Ekstra; (2) Memperluas Pangsa Pasar; (3) Membangun Hubungan lebih erat dengan Pelanggan Potensial.

Hal yang dapat dilakukan untuk mencapai tujuan ini adalah dengan memberikan pelayanan ekstra bagi pelanggan, baik itu pelayanan sebelum, selama proses transaksi hingga pasca transaksi. Dengan adanya tambahan pelayanan ekstra bagi pelanggan, kebutuhan dan kepuasan pelanggan akan akan terpenuhi sehingga dalam jangka panjang loyalitas pelanggan akan terbangun.

Mengacu pada analisa SWOT terhadap kondisi peusahaan dan peluang pasar yang terbuka lebar, maka hal pertama yang dapat dilakukan dalam memenuhi tujuan ini adalah dengan terlebih dahulu mengenali situasi pasar dan kebutuhan konsumen. Bila sudah terpenuhi, maka PT. IMPAQ ERA BARU dapat menetapkan strategi sesuai dengan kebutuhan yang ada. Strategi yang dimaksud dapat melalui pengembangan produk produk yang sudah ada atau melalui promosi agar produk - produk yang ditawarkan dapat sampai kepada konsumen.

Pelanggan potensial sudah selayaknya mendapatkan prioritas khusus, baik dari segi pelayanan maupun perhatian. PT. IMPAQ ERA BARU dapat menawarkan produk produk baru yang hendak dikeluarkan melalui brosur yang secara rutin diberikan kepada para pelanggan. Hal ini dimaksudkan agar dapat mempertahankan pelanggan lama sekaligus menciptakan peluang untuk memperoleh pelanggan - pelanggan baru yang lebih potensial.

Dengan demikian, tolak ukur yang tepat untuk mengukur keberhasilan pencapaian tujuan strategis dalam perspektif pelanggan adalah:

1. Tingkat Kepuasan Pelanggan (Customer Satisfaction)

Kesetiaan pelanggan merupakan faktor penting yang harus dijadikan tujuan dalam meningkatkan kepercayaan pelanggan. Bila pelanggan setia dan memiliki tingkat retensi yang tinggi, jumlah volume transaksi akan semakin besar dan pelanggan akan menyambut baik produk - produk baru lain yang ditawarkan PT. IMPAQ ERA BARU. Tolak ukur ini dapat dilakukan melalui survey kepada pelanggan secara berkala. Survey yang dapat digunakan adalah survey yang dapat mengukur seberapa besar kesenjangan ( $g a p)$ antara harapan (expectation) pelanggan dan persepsi pelanggan terhadap pelayanan yang diberikan PT. IMPAQ ERA BARU.

2. Penguasaan Pangsa Pasar (market share)

Tolak ukur ini merupakan tolak ukur yang penting karena terkait erat dengan visi PT. IMPAQ ERA BARU. Pangsa pasar dihitung dari besarnya jumlah pelanggan yang dimiliki PT. IMPAQ ERA BARU dibandingkan dengan total jumlah pelanggan furnitur di sekitar wilayah kerja PT. IMPAQ ERA BARU.

3. Kemampuan untuk mempertahankan pelanggan lama atau retensi pelanggan (customer retention)

Tolak ukur ini dapat dihitung dengan cara membandingkan antara jumlah pelanggan yang tetap setia terhadap produk yang ditawarkan PT. IMPAQ ERA BARU 
untuk suatu periode tertentu dengan seluruh pelanggan yang menggunakan produk tersebut dari periode sebelumnya. Hasilnya kemudian dibandingkan dengan standar atau kriteria yang telah ditentukan untuk menilai apakah PT. IMPAQ ERA BARU dapat mempertahankan pelanggannya dengan baik atau tidak.

4. Kemampuan memperoleh pelanggan baru atau akuisisi pelanggan (customer acquisition)

Penambahan pelanggan baru membuktikan tingkat kepercayaan terhadap pelayanan PT. IMPAQ ERA BARU telah meningkat. Banyaknya dan beragamnya produk furnitur yang tersedia di PT. IMPAQ ERA BARU memberikan peluang besar bagi tim pemasaran untuk meraih pelanggan baru. Hal yang dapat dilakukan adalah dengan lebih aktif menawarkan dan memperkenalkan produk tersebut. Tolak ukur ini dapat dilihat dari besarnya jumlah pelanggan baru yang berhasil diperoleh PT. IMPAQ ERA BARU dibandingkan dengan estimasi jumlah pelanggan potensial atau dibandingkan dengan estimasi kemampuan pesaing. Hasilnya dibandingkan dengan standar yang telah ditentukan oleh perusahaan.

Proses internal merupakan salah satu komponen yang sangat penting dalam melakukan pencapaian tujuan perusahaan. Dalam perspektif proses internal, tindakan tindakan yang terdapat di dalam proses internal perusahaan diidentifikasi agar mencapai tujuan perusahaan. Scorecard dalam perspektif proses bisnis internal dapat membantu manajer untuk mengukur seberapa besar tanggapan dari pasar atas setiap produk atau jasa yang ditawarkan berdasarkan proses yang ada dan apakah sudah memenuhi tuntutan kebutuhan pelanggan.

Sasaran strategis dalam proses bisnis internal terkait dengan strategi di dua perspektif sebelumnya yang telah diterapkan perusahaan. Sasaran - sasaran strategis tersebut adalah: (1) Mengembangkan Produk Baru; (2) Meningkatkan Kinerja Operasional Perusahaan.

Langkah awal yang dapat dilakukan sebelum mengembangkan produk baru adalah dengan melakukan studi kelayakan terhadap situasi pasar. Setelah informasi mengenai keadaan pasar sudah dapat dikenali, pihak manajemen dapat langsung mengembangkan produk - produk baru yang memiliki nilai lebih di mata pelanggan. Tolak ukur yang dirasa tepat untuk mengukur sasaran strategis dalam proses bisnis internal adalah dengan cara menghitung Pendapatan Produk Baru.

Loyalitas pelanggan dapat dipelihara dengan cara melalui penambahan jumlah produk yang dapat memberikan nilai tambah bagi pelanggan. Tolak ukur ini berguna untuk mengukur tingkat keberhasilan produk - produk baru yang diluncurkan dalam meraih pendapatan selama periode tertentu. Misalnya, dengan menghitung persentase pendapatan yang diperoleh dari produk baru untuk suatu periode tertentu dibandingkan dengan total pendapatan PT. IMPAQ ERA BARU dalam periode tersebut. Bila perolehan pendapatan PT. IMPAQ ERA BARU dari produk baru tersebut mempengaruhi kenaikan pos laporan keuangan, maka dapat dikatakan bahwa tujuan perusahaan sudah tercapai.

Penyampaian produk kepada pelanggan dapat dilakukan secara efisien, konsisten dan tepat waktu. Kehadiran pesaing lain yang menawarkan kualitas produk yang beragam dapat menjadi ancaman besar bagi PT. IMPAQ ERA BARU, terutama terkait dalam upayanya untuk mempertahankan loyalitas pelanggan yang selama ini telah terjalin. PT. IMPAQ ERA BARU perlu memperbaiki kualitas pelayanannya kepada pelanggan agar dapat meningkatkan kepuasan pelanggan. Hal yang dapat dilakukan untuk mendukung strategi tersebut adalah dengan mempermudah mekanisme pembelian melalui kredit ringan atau cicilan. 
Tolak ukur yang dapat digunakan dalam meningkatkan kinerja operasional perusahaan adalah:

1. Employee Service Performance

Tolak ukur ini dapat digunakan PT. IMPAQ ERA BARU untuk memperoleh input dari pelanggan atas pelayanan yang mereka peroleh. Sebagai contoh, apakah selama proses pengenalan produk hingga penyampaian produk kepada pelanggan sudah sesuai dengan tujuan jangka panjang perusahaan dan apakah kebutuhan pelanggan sudah terpenuhi hingga mencapai tahap terpuaskan atau justru tidak ada perbedaan perlakuan kepada pelanggan yang diberikan PT. IMPAQ ERA BARU dibandingkan pesaing lainnya. Semakin tinggi Employee Service Performance, maka semakin baik pula kegiatan operasi perusahaan.

2. Waktu Proses Produksi

Tolak ukur ini digunakan untuk mengukur efisiensi dari proses produksi yang dilakukan. Semakin efisien proses produksi suatu barang maka biaya yang dikeluarkan untuk melaksanakan aktivitas akan semakin rendah sehingga kepuasan pelanggan akan tercapai karena dapat memperoleh barang pesanan lebih cepat.

Perspektif pembelajaran dan pertumbuhan pada umumnya terdiri dari faktor sumber daya manusia, sistem dan prosedur organisasi. Ketiga faktor tersebut merupakan investasi jangka panjang perusahaan yang tidak memiliki bentuk dan wujud. Contoh umum dalam perspektif pembelajaran dan pertumbuhan adalah pelatihan pegawai dan budaya perusahaan.

Secara umum, terdapat tiga tujuan utama yang dapat dicapai oleh PT. IMPAQ ERA BARU dalam perspektif pertumbuhan dan pembelajaran, yaitu: (1) Meningkatkan Profesionalisme Pegawai; (2) Mengembangkan Kemampuan Sistem Informasi; (3) Menciptakan Budaya Organisasi yang Kondusif.

Meningkatkan Profesionalisme kerja akan berdampak positif terhadap peningkatan kualitas pelayanan terhadap pelanggan dan hal ini akan berdampak positif pula terhadap peningkatan kepuasan pelanggan yang pada akhirnya meningkatkan pendapatan perusahaan.

Untuk meningkatkan profesionalisme pegawai dan kapabilitas karyawan dapat dibangun melalui dua cara, yaitu dengan membangun kapabilitas manajer dan membangun kapabilitas karyawan.

Pembangunan kapabilitas manajer dapat dilakukan dengan cara: (1) Menerapkan pengetahuan yang diperoleh selama masa pelatihan ke dalam tahapan pengelolaan dan pelaksanaan; (2) Mengelola setiap perubahan yang terjadi di dalam internal perusahaan;(3) Mengelola setiap kemungkinan resiko yang akan dihadapi selama masa kerja.

Kapabilitas karyawan ditentukan oleh dua faktor: (1) technical know-how dan (2) social know-how. PT. IMPAQ ERA BARU dapat membangun kapabilitas karyawan dengan melakukan beberapa inisiatif stratejik, diantaranya adalah: (1) Pembangunan kapabilitas dalam menerapkan pengetahuan ke dalam perkerjaan; (2) Kemampuan karyawan bekerja dalam tim.

Kesalahan umum yang sering dilakukan oleh perusahaan dalam membangun kapabilitas karyawan adalah kurangnya kesempatan yang diberikan kepada karyawan untuk menerapkan pelatihan dan pendidikan yang diterimanya saat implementasi pekerjaan.

Tolak ukur yang dapat digunakan dalam sasaran strategis ini adalah dengan menggunakan strategic skill coverage ratio. Tolak ukur ini berguna untuk mengukur tingkat pemahaman dan keahlian pegawai dalam menerjemahkan visi dan misi 
perusahaan ke dalam tataran aplikasi. Pengukuran terhadap keahlian ini dapat dilakukan melalui analisis kebutuhan peningkatan kualitas pegawai terhadap pencapaian target perusahaan. Tolak ukur yang dapat digunakan dalam sasaran strategis yang kedua adalah pengaruh teknologi terhadap produktifitas. Tolak ukur ini berguna untuk mengukur sejauh mana efek dari pemanfaatan teknologi dalam menunjang kegiatan operasional perusahaan. Ukuran ini dapat membandingkan proses sebelum dan sesudah pemanfaatan teknologi. Apakah pemanfaatan teknologi yang menggunakan biaya yang besar mampu memangkas pos - pos yang menjadi cost center perusahaan atau tidak ada pengaruhnya sama sekali.

Mengembangkan kemampuan sistem informasi dengan memanfaatkan teknologi dapat menunjang ketersediaan data dan informasi dalam melayani pelanggan.. Dalam rangka mengembangkan kemampuan sistem informasi, PT. IMPAQ ERA BARU dapat melakukan berbagai cara, diantaranya adalah: (1) Pemanfaatan teknologi; (2) Penyediaan Fasilitas Relationship Manager/Customer Service; (2) Menciptakan Budaya Organisasi yang Kondusif.

Produktivitas pekerja sangat ditentukan oleh teknologi yang tersedia bagi pekerja dalam melaksanakan tugasnya. Kecanggihan teknologi yang tersedia bagi pekerja ditentukan juga oleh kondisi persaingan dan tuntutan kebutuhan pelanggan. Jika kebutuhan pelanggan telah terpenuhi oleh pesaing dengan teknologi canggih, produk yang ditawarkan oleh PT. IMPAQ ERA BARU akan semakin tertinggal. Hal ini tentu saja dapat mempengaruhi kualitas produk yang dihasilkan serta proses waktu penyelesaian suatu produk akan semakin lama.

Nilai pelanggan bagi perusahaan merupakan hal yang sangat penting untuk diperhatikan. Penyediaan fasilitas relationship manager/customer service dalam perusahaan dapat mempererat hubungan antara perusahaan dengan pelanggan. Setiap keluhan yang diterima oleh pelanggan dapat menjadi sarana perbaikan untuk terus memperbaiki diri. Hal ini tidak dapat direalisasi bila tidak didukung oleh sarana teknologi informasi yang memadai dan kualitas sumber daya manusia yang mumpuni.

Perspektif ini penting untuk menjamin adanya proses yang berkesinambungan terhadap upaya pemberian motivasi dan inisiatif yang sebesar - besarnya bagi pegawai. Hal ini perlu dilakukan agar dapat meningkatkan profesionalisme kerja sekaligus meningkatan pendapatan perusahaan.

Penerapan budaya organisasi yang kondusif diharapkan dapat memacu kinerja pegawai dalam meningkatkan produktifitasnya selama bekerja. Pegawai yang telah memenuhi target perusahaan harus mendapat reward yang sebanding dengan kinerjanya dan demikian juga sebaliknya.

Tolak ukur yang dapat digunakan dalam memenuhi tujuan - tujuan tersebut adalah:

1. Tingkat kepuasan Karyawan (employee satisfaction)

Tingkat kepuasan merupakan ukuran seberapa banyak harapan - harapan karyawan yang dapat terpenuhi dibandingkan dengan persepsi mereka terhadap apa yang telah diperoleh dari perusahaan, seperti kompensasi, budaya kerja, dan juga mekanisme peningkatan jenjang karir di dalam perusahaan.

2. Retensi Pekerja

Tujuan retensi pekerja adalah untuk mempertahankan selama mungkin para pekerja yang diminati perusahaan. Tolak ukur yang dapat digunakan adalah dengan melihat tingkat perputaran pegawai (employee turnover) dalam suatu periode di perusahaan tersebut. Apabila tingkat keluar masuknya pegawai tinggi, maka perlu dilakukan pembenahan agar para pegawai loyal terhadap perusahaan. 


\section{Strategi map balanced scorecard}

Rancangan Sistem Pengukuran Kinerja berbasis Balanced Scorecard dapat disusun dalam bentuk seperti yang terlihat dalam Gambar 3 .

Gambar 3. Rancangan Sistem Pengukuran Kinerja Berbasis Balanced Scorecard PT. IMPAQ ERA BARU

\begin{tabular}{|c|c|c|}
\hline \multirow[b]{2}{*}{ Sasaran Strategis } & \multicolumn{2}{|c|}{ Ukuran Strategis } \\
\hline & $\begin{array}{l}\text { Lag Indicator } \\
\text { (Indikator Akibat) }\end{array}$ & $\begin{array}{c}\text { Lead Indicator } \\
\text { (Indikator Sebab) }\end{array}$ \\
\hline $\begin{array}{l}\text { Perspektif Keuangan } \\
\text { A1- Meningkatkan Pendapatan } \\
\text { Perusahaan } \\
\text { A2- Mengelola Pendapatan Piutang }\end{array}$ & $\begin{array}{l}\text { Return on Asset } \\
\text { Profit Margin on Sales }\end{array}$ & Receivable Turnover \\
\hline $\begin{array}{l}\text { Perspektif Pelanggan } \\
\text { I1- Meningkatkan Loyalitas } \\
\text { Pelanggan Melalui Pelayanan Ekstra } \\
\text { I2- Memperluas Pangsa Pasar } \\
\text { I3- Membangun Hubungan lebih erat } \\
\text { dengan Pelanggan Potensial }\end{array}$ & $\begin{array}{l}\text { Kepuasan Pelanggan } \\
\text { Pangsa Pasar }\end{array}$ & $\begin{array}{l}\text { Customer Retention } \\
\text { Customer Acquisition }\end{array}$ \\
\hline $\begin{array}{l}\text { Perspektif Proses Bisniss Internal } \\
\text { S1- Mengembangkan Produk Baru } \\
\text { S2- Meningkatkan Kinerja } \\
\text { Operasional Perusahaan }\end{array}$ & $\begin{array}{l}\text { Penghitungan Pendapatan } \\
\text { Kinerja Operasional } \\
\text { Perusahaan Menjadi Baik } \\
\text { Efisiensi dan Efektifitas } \\
\text { Kerja }\end{array}$ & $\begin{array}{l}\text { Penawaran Produk Baru } \\
\text { Employee Service } \\
\text { Performance } \\
\text { Waktu Proses Produksi }\end{array}$ \\
\hline $\begin{array}{l}\text { Perspektif Pertumbuhan dan } \\
\text { Pembelajaran } \\
\text { N1- Meningkatkan Profesionalisme } \\
\text { Pegawai }\end{array}$ & Kepuasan Pegawai & $\begin{array}{l}\text { Strategic Skill Coverage } \\
\text { Ratio }\end{array}$ \\
\hline $\begin{array}{l}\text { N2- Mengembangkan Kemampuan } \\
\text { Sistem Informasi }\end{array}$ & $\begin{array}{l}\text { Peningkatan Produktivitas } \\
\text { Kerja }\end{array}$ & $\begin{array}{l}\text { Pengaruh Teknologi } \\
\text { terhadap Produktifitas }\end{array}$ \\
\hline $\begin{array}{l}\text { N3- Menciptakan Budaya Organisasi } \\
\text { yang Kondusif }\end{array}$ & Employee Turnover & Retensi Pegawai \\
\hline
\end{tabular}

Sumber: Berbagai data setelah diolah

\section{Simpulan}

Pertumbuhan ekonomi suatu negara tidak dapat dipisahkan dari berbagai faktor yang turut mempengaruhi dan mewarnai jalannya roda perekonomian suatu negara. Faktor politik, sosial, dan keamanan yang stabil dapat mendorong pertumbuhan ekonomi suatu bangsa. Agar dapat bersaing dalam persaingan global, perusahaan harus dikelola secara profesional dan efisien. Pemanfaatan teknologi mutlak digunakan untuk meningkatkan kualitas pelayanan. Namun demikian, profesionalisme para pegawai ikut juga menentukan daya saing dan keberhasilan PT. IMPAQ ERA BARU dalam memberikan produk terbaik dibandingkan para pesaingnya.

Semakin meningkatnya jumlah perusahaan furnitur secara langsung dapat mempengaruhi tingkat pendapatan PT. IMPAQ ERA BARU. Oleh karena itu, PT. IMPAQ ERA BARU harus secara berkelanjutan berupaya memelihara keseimbangan kekuatan internalnya dalam menghadapi ancaman dari para pesaingnya. Mengejar 
keuntungan secara finansial dalam jangka panjang sulit untuk diraih jika hanya mengandalkan data laporan keuangan saja. Terdapat banyak aspek yang harus diperhatikan dan ditingkatkan guna menunjang tujuan perusahaan, termasuk dengan mulai memperbaiki sistem pengukuran kinerja yang mampu menerjemahkan visi, misi, dan strategi perusahaan tidak hanya dalam tahapan perumusan strategi saja, tetapi sampai ke tahap implementasi.

Balanced Scorecard, konsep yang diperkenalkan Kaplan dan Norton, merupakan suatu sistem pengukuran kinerja yang dapat menerjemahkan visi, misi, dan strategi ke dalam berbagai ukuran dan tujuan yang meliputi empat perspektif, yaitu: keuangan, pelanggan, proses bisnis internal, dan pembelajaran dan pertumbuhan.

Balanced Scorecard tidak hanya memberikan suatu kemungkinan bagi pihak manajemen dalam mengukur kinerja, namun juga mampu mensinergiskan program dalam tahap perencanaan hingga tahap implementasi. Sistem Balanced Scorecard dapat mengkomunikasikan tahapan perencanaan stratejik, sasaran stratejik, dan inisiatif stratejik menjadi lebih komprehensif. Rencana stratejik yang komprehensif kemudian diimplementasikan ke dalam berbagai program dalam tahap penyusunan program hingga menghasilkan rencana usaha laba untuk jangka panjang. Berbagai program tersebut kemudian dijadikan aktivitas tahunan, seperti contohnya dalam tahap penyusunan anggaran. Sehingga pada akhirnya, langkah - langkah yang dipilih dalam penyusunan anggaran tidak dapat dipisahkan dengan program, inisiatif, stratejik, sasaran stratejik, strategi, visi, dan misi perusahaan.

Dengan semakin stabilnya kondisi perekonomian Indonesia, PT. IMPAQ ERA BARU diharapkan dapat menerapkan Balanced Scorecard untuk menopang pencapaian visi dan misi perusahaan sekaligus sebagai langkah awal untuk meningkatkan kinerja perusahaan.

\section{Saran}

PT. IMPAQ ERA BARU dapat menggunakan Balanced Scorecard tidak hanya sebagai alat ukur performa, tetapi juga sebagai alat komunikasi atas tujuan yang hendak dicapai bagi pihak manajemen terhadap karyawannya ataupun sebaliknya.

PT. IMPAQ ERA BARU dapat menerapkan empat perspektif Balanced Scorecard dalam tataran aplikasi secara sinergis. Adanya ketimpangan pihak manajemen dalam menitikberatkan satu perspektif terhadap perspektif yang lain akan dapat merusak strategi yang telah ditetapkan. Kepuasan pelanggan dengan didukung proses bisnis internal yang baik dan sumber daya manusia yang berkualitas akan dapat menunjang kegiatan operasional PT. IMPAQ ERA BARU.

Pada akhirnya, pihak manajemen PT. IMPAQ ERA BARU harus ikut terlibat secara penuh untuk membawa perusahaan ke arah yang lebih baik.

\section{Daftar Pustaka}

Adhariani, Desi, Akuntansi Biaya: Penekanan Manajerial, edisi kesebelas Jilid 1, terjemahan dari Cost Accounting: A Managerial Emphasis, eleventh edition, PT Indeks Kelompok Gramedia, 2005.

Andriana, Denny, Pendekatan Sistem Manajemen Strategis Berbasis Balanced Scorecard (Usulan untuk PT. Bank Perkreditan Rakyat Purnaloka Bhakti), Fakultas Ekonomi Universitas Indonesia, 2004.

Atkinson, A.A., Banker, R.D., Kaplan, R.S., Young, S.M., Management Accounting, Englewood Cliff, Prentice Hall, 1995. 
Evanola, Radita, Penerapan Kebijakan Pengelolaan Piutang dan Dampaknya Terhadap Efektifitas Modal Kerja (Studi Kasus pada PT. IMPAQ ERA BARU), Fakultas Ekonomi Universitas Islam As-Syafi'iyah, 2012.

Hansen, Don R Mowen \& Maryanne M., Management Accounting $5^{\text {th }}$ ed., South Western College Publishing, 2000.

Horngren, Charles T., Foster, George., Datar, Srikant M., Rajan, Madhav, \& Ittner, Chris, Cost Accounting: A managerial Emphasis, 13/E, Prentice Hall, 2009.

Kaplan, Robert S, dan David P. Norton, The Balanced Scorecard: Translating Strategy into Action, Harvard Business Review, Massachusets, 1996.

Kaplan, Robert S, dan David P. Norton, Balanced Scorecard: Menerapkan Strategi Menjadi Aksi, terj. Peter R. Yossi Pasla, Jakarta, Erlangga, 2000.

Kaplan, Robert S, dan David, P. Norton, The Strategy Focused Organization: How Balanced Scorecard Companies Thrive in The New Business Environment, Harvard Business Review, Massachusets, 2001.

Kwary, Deny Arnos, Akuntansi Manajerial edisi 8, Buku 1, terjemahan dari Accounting Managerial $8^{\text {th }}$ edition, Salemba Empat, 2009.

Kwary, Deny Arnos, Akuntansi Manajerial edisi 8, Buku 2, terjemahan dari Accounting Managerial $8^{\text {th }}$ edition, Salemba Empat, 2009.

M. Treaty dan F. Wiersema, The Discipline of Market Leader, Choose Your Customers, Narrow Your Focus, Dominate Your Market, M.A, Addison-Wesley, 1995.

Mulyadi, Alat Manajemen Kontemporer untuk Pelipatganda Kekayaan Perusahaan: Balanced Scorecard, Jakarta, PT. Salemba Emban Patria, 2001.

Porter, Michael, Competitive Strategy: Techniques for Analyzing Industries and Competitors, New York, The Free Press, 1980.

Robbins, Stephen P dan Mary Coulter, Manajemen edisi 6, edisi asli 1999, Prentice Hall, Inc. Englewood Cliffs, NJ 07632, alih bahasa Drs. T. Hermaya, Jakarta, PT. Prenhallindo, 1999.

Sony Yuwono, dkk, Petunjuk Praktis Penyusunan Balanced Scorecard Menuju Organisasi yang Berfokus pada Strategi, Jakarta, PT. Gramedia Pustaka Utama, 2002.

Sumber Data PT. IMPAQ ERA BARU 